\title{
Em busca de uma modernidade nacional: o movimento modernista e o projeto político-cultural do regime Vargas
}

\author{
In search of a national modernity: the modernist movement and the \\ political-cultural project of the Vargas regime
}

\section{Bruno Gontyjo do Couto ${ }^{1}$}

Resumo: O presente artigo pretende lançar um novo olhar sobre as mediações históricas, figuradas em trajetórias e práticas dispersas no âmbito da política e da cultura, que fomentaram a articulação entre a perspectiva artística utópica do movimento modernista e o projeto políticocultural do regime Vargas. Interessa compreender quais as "afinidades eletivas" que ensejaram o cruzamento ambíguo, mas bem sucedido, entre a utopia artístico-cultural modernista e as aspirações político-intelectuais das facções no comando do Estado naquele período. Desse modo, em um primeiro momento, partimos para a análise do quadro político-cultural dos anos 10 no Brasil e na Europa, mapeando a presença das perspectivas nacionalistas, nativistas e modernistas que vão culminar na formação do movimento modernista brasileiro. Feito isto, nos propomos a entender a particularidade que essa proposta cultural porta ao conceber uma linguagem capaz de conciliar os termos do moderno e do nacional. Em um segundo momento, mostraremos como essa tentativa de conciliação correspondia a uma série de anseios compartilhados por facções intelectuais e políticas do país. Partindo desse cenário, procuramos demonstrar os caminhos pelos quais se forma a articulação entre modernistas e o regime Vargas.

Palavras-chave: Movimento modernista; Regime Vargas; Cultura; Política; Modernidade

\footnotetext{
1 Mestre em Sociologia pela Universidade de Brasília (UnB), possui pesquisas desenvolvidas nas áreas de Sociologia da Cultura e Sociologia Urbana, com ênfase na história cultural de projetos de modernidade e modernização ligados à renovação de espaços urbanos no Brasil.
}

Latitude, Vol. 9, no 1, pp. 133-170, 2015

DOI: https://doi.org/10.28998/2179-5428.20150107 
Em busca de uma modernidade nacional: o movimento modernista e o projeto político-cultural do regime Vargas

\begin{abstract}
This article intends to develop a new perspective on the historical mediations - figured in trajectories and practices dispersed within the political and cultural fields - that engendered the relationship between the cultural artistic perspective of the Brazilian Modernist Movement and the political and cultural project of the Vargas regime (1930-1945). We are looking for the "elective affinities" that produced this ambiguous but successful intersection between the artistic and cultural modernist utopia and the political and intellectual aspirations of the groups in charge of the Brazilian state in that period. Therefore, in the first part of the article, we analyzed the context of 1910' decade in Brazil and Europe, mapping the presence of the nationalist, nativist and modernist perspectives that will inspire the formation of the Brazilian Modernism. Mainly, we tried to understand the particularities that this cultural proposal showed when it tried to design a language able to adjust the terms of the modern and the national. In the second part, we demonstrate how this attempt to conciliate the modern and the national corresponded to aspirations shared by intellectuals and political groups in Brazil. Through this scenario, we demonstrate the historical ways that linked Modernist Movement and the political regime.
\end{abstract}

Key Words: Brazilian Modernism; Vargas Dictatorship; Culture; Politics; Modernity

\title{
Introdução
}

Inspirado nas obras de Daniel Pécault e Nicolau Sevcenko, o presente artigo pretende lançar um novo olhar sobre as mediações históricas, figuradas em trajetórias e práticas dispersas no âmbito da política e da cultura, que fomentaram a articulação entre a perspectiva artística utópica do movimento modernista e o projeto político-cultural do regime Vargas.

Para nós, interessa compreender, a partir de um quadro histórico específico marcado pelo engate entre cultura e política, quais as "afinidades eletivas" que ensejaram o cruzamento ambíguo, mas bem sucedido, entre a 
utopia artístico-cultural modernista e as aspirações político-intelectuais das facções no comando do Estado brasileiro naquele período.

Se por um lado, esse cruzamento retoma a aliança entre Estado e ciência presente no projeto republicano, como parte de uma visão iluminista de sociedade que confere papel de protagonismo aos intelectuais dentro da vida política, por outro, os conteúdos e princípios que fundamentam esse casamento são bem distintos daqueles que caracterizavam, em um primeiro momento, o movimento políticointelectual de 1870 e, mais tarde, a geração da belle époque tropical. Nesse novo contexto, a tarefa de implantação de uma Civilização (à europeia) no Brasil vai ser substituída pelo esforço de construção de uma modernidade nacional.

Com a transformação do cenário sociocultural e econômico mundial a partir da Primeira Guerra, o termo "moderno" vai substituir a palavra "civilização" como valor aspirado, substituindo o aspecto cortesão, racionalista e determinista da última por uma combinação de instintividade, vitalidade, frenesi e imediatismo presentes no primeiro (SEVCENKO, 1992, p. 178). A era do automóvel, do avião, da propaganda e do cinema se mostrava cada vez mais veloz e volátil, de modo que uma referência tão determinista e linear como a ideia oitocentista de civilização já não dava mais conta de representar as aspirações e anseios daquele novo cenário. O trauma da guerra também havia criado ressentimentos com relação ao conteúdo imperialista da palavra. Simultaneamente, forma-se um desejo generalizado de renovação, uma espécie de obsessão por um novo equilíbrio que unisse os elementos fragmentados pela guerra e dispersos pela volatilidade dos novos tempos. Dessa forma, o termo "moderno" procurava atender a essas demandas, adjetivando tudo o que estivesse ligado a uma espécie de "presente profético" (SEVCENKO, 1992, p.99).

Por outro lado, a fome por vitalidades, por essências e por sentimentos de comunhão que superassem o aspecto corrosivo de um mundo veloz e de uma guerra sem precedentes, tendia a incorporar o espírito nacionalista do pós-guerra, criando um enorme apelo por tudo que fosse coletivo e autenticamente nacional. $\mathrm{O}$ anseio por um novo equilíbrio fundia-se com os desejos de comunhão e pureza projetados sobre um possível subterrâneo nacional. 
Em busca de uma modernidade nacional: o movimento modernista e o projeto político-cultural do regime Vargas

Esse apelo generalizado pelo moderno e pelo nacional, com os respectivos desejos de equilíbrio, pureza e comunhão, chega ao Brasil através de uma série de mediações políticas, econômicas e culturais. Sendo alocado de acordo com contextos e situações que já estavam instalados no país, esse apelo reconfigura os anseios de construção de um novo Brasil, presentes desde a geração intelectual de 1870, contribuindo para a produção de uma vontade compartilhada de renovação social, cultural e política.

Nesse momento ainda não é possível precisar os termos dessa equação, mas desde já partimos da constatação que foi exatamente essa vontade compartilhada em busca de um novo equilíbrio capaz de combinar os termos do "moderno" e do "nacional", a matéria responsável por viabilizar a liga entre a utopia artística modernista e a perspectiva política do novo regime. De certa forma, o anseio por renovação sociocultural presente no modernismo sintonizou-se com o desafio de unificação política e atualização socioeconômica enfrentado pelo regime Vargas.

A justaposição das trajetórias de facções intelectuais e políticas torna-se possível por conta do alinhamento - consciente e inconsciente - de anseios, preocupações e aspirações que, em última medida, gravitam em torno de um projeto de sociedade comum: a modernidade nacional. Intersecções presentes na própria visão de mundo (social) dos dois grupos tornam possível uma articulação que a princípio pareceria contraditória ou suspeita.

Nesse contexto, a "modernidade brasileira" surge como uma utopia, na medida em que se constitui como aspiração futura de emancipação, independência e autonomia político-cultural de uma sociedade, mas também como uma ideologia, enquanto protocolo de conduta vinculado à manutenção de coalizões entre elites intelectuais e políticas no campo de poder.

Utopia e ideologia, arte e política reunidas em torno da busca por uma modernidade nacional.

Assim, em um primeiro momento do artigo, partimos para a análise do quadro político-cultural dos anos 10 no Brasil e na Europa, mapeando a presença das perspectivas nacionalistas, nativistas e modernistas que vão culminar na formação do movimento modernista brasileiro. Feito isto, nos propomos a entender a particularidade que essa proposta cultural porta ao conceber uma linguagem capaz de conciliar os termos do moderno e do 
nacional. Em um segundo momento, mostraremos como essa tentativa de conciliação correspondia a uma série de anseios compartilhados por facções intelectuais e políticas do país. Partindo desse cenário, procuramos demonstrar os caminhos pelos quais se forma a bem sucedida articulação entre intelectuais modernistas e o regime Vargas, percebendo as conexões existentes entre utopia artística e ideologia política.

\section{Estética modernista e o ajuste entre os termos do moderno} e do nacional

A partir de meados dos anos 10, principalmente com a eclosão da grande guerra, uma febre nacionalista, preocupada com os rumos do Brasil como nação diante do cenário internacional, tomou conta do cenário público e intelectual no Brasil. Nesse momento, diversos intelectuais defenderam uma postura mais ativa, sinalizando a importância do envolvimento da inteligência brasileira no processo de conscientização nacional, contribuindo para formação de um povo-cidadão interessado nos destinos da pátria.

No mesmo período, um conjunto de intelectuais enseja, através de suas práticas e discursos, o que seria o princípio de uma onda nativista no Brasil, difundindo, pouco a pouco, o interesse por temas e objetos vinculados às tradições coloniais, populares e regionais. Essa onda nativista, de certo modo, acompanha a febre nacionalista, mas não é necessariamente condicionada por ela. Esse duplo cenário irá reverberar ao longo de toda década de 10 e 20, sendo decisivo na constituição do movimento modernista.

Ainda no ano de 1914, Alberto Torres publica o livro “O problema nacional brasileiro", um conjunto de textos publicados anteriormente em jornais, nos quais critica a postura de distanciamento das elites políticas com relação à situação do povo e da pátria, a inadequação das instituições republicanas com relação à realidade e caráter brasileiros, além da postura diletante e indiferente dos intelectuais. O sociólogo estava preocupado com a nova fase de concorrência do imperialismo, diagnosticando o estado de dissolução da nação como um mal a ser combatido. Contudo, diferentemente da geração intelectual de 1870, Torres não atribuía o problema ao povo brasileiro, condenando a descrença com relação às raças 
Em busca de uma modernidade nacional: o movimento modernista e o projeto político-cultural do regime Vargas

que aqui habitavam. Para o autor, os responsáveis por esse cenário eram as elites dirigentes e intelectuais (TORRES, 1938, p. 277).

Era preciso forjar a consciência nacional a partir de um ato deliberado, racional, a partir de cima. Os intelectuais precisavam abdicar da "atitude crítica e de diletantismo literário" em favor da "coragem da iniciativa e da responsabilidade de solver". A mensagem de Torres impactou uma série de intelectuais, tendo profunda influência sobre o grupo católico que mais tarde contribuiria com a política educacional do regime Vargas.

No ano de 1916, o poeta Olavo Bilac, protagonista intelectual da belle époque carioca, funda, junto a um grupo de intelectuais, juristas e políticos eminentes, a Liga da Defesa Nacional, cujos objetivos eram basicamente: serviço militar obrigatório, educação cívico-militar e estímulo ao espírito patriótico. A organização foi um verdadeiro marco, influenciando intelectuais, estudantes e militares, além de estimular a formação de organizações semelhantes nos anos seguintes, como a Liga Nacionalista do Brasil, a Propaganda Nativista, Ação Social Nacionalista, etc.

Em suma, um sentimento de missão nacional começa a ser propagado entre os intelectuais naquele momento. Havia uma percepção generalizada de que a sua posição os incumbia da tarefa de fazer o povo consciente dos seus interesses e dos destinos da pátria, conformando uma comunidade nacional verdadeiramente organizada. Assim, esse período reatualiza o propósito de disponibilizar a inteligência em prol da reorganização da nação.

Por outro lado, esse mesmo período é marcado pela atuação daqueles que seriam os precursores de uma onda nativista no Brasil. Nos anos 10, esse novo segmento de intelectuais passa a se envolver com o estudo e a promoção de elementos culturais ligados às tradições históricas, populares e regionais do país. Apesar de não compartilharem necessariamente da mesma perspectiva da euforia nacionalista, os intelectuais nativistas também partiam da crença na existência de uma nação inconsciente, implícita nos hábitos e costumes do povo. Diretamente envolvidos na superação do olhar pessimista diante das raças brasileiras, eles estavam interessados justamente no desvelamento de uma espécie de subterrâneo nacional. 
O início do movimento arquitetônico conhecido como "neocolonial" é atribuído ao ano de 1914, quando o arquiteto português Ricardo Severo profere a conferência "A arte tradicional no Brasil". Nessa conferência, Severo critica a indiferença dos arquitetos brasileiros com relação às tradições ligadas "à formação da nacionalidade", opondo-se à imitação dos estilos europeus em favor da apreensão de estilos desenvolvidos ao longo da história nacional. Segundo o arquiteto, esses estilos incorporavam um modo de expressão adaptado às condições do país à época, portando uma parte do próprio "espírito nacional". Severo afirmava que era preciso formar um novo estilo que agregasse elementos arquitetônicos tradicionais, resgatando parte da própria nacionalidade, para, então, estiliza-los conforme a época atual (SANTOS, SILVA \& DANTAS, 2012).

A perspectiva de Severo fomentou a ação de todo um conjunto de arquitetos - como Victor Dubugras, Heitor de Mello e Lúcio Costa - que passou a projetar construções marcadamente inspiradas na estética barroca da época colonial.

Contudo, sem sombra de dúvida, o principal representante desse segmento nativista foi o escritor Afonso Arinos de Melo Franco. Desde o começo do século XX, o escritor vivia na cidade de Paris e muito possivelmente foi influenciado pelo exotismo que tomava conta da capital francesa nos anos 10. Artistas e intelectuais sediados em Paris tinham uma verdadeira fome por tudo o que estivesse vinculado a um "Outro exótico", desde os elementos de matriz africana e pré-colombiana até o jazz feito por músicos norte-americanos negros. Essa obsessão pelo exótico estava vinculada à representação de "pureza" e "espontaneidade" que aqueles intelectuais atribuíam às manifestações artísticas e culturais de povos tidos como "primitivos" e "exóticos" (SEVCENKO, 1992, p. 278).

Como sugerido por Nicolau Sevcenko, a partir da perspectiva parisiense, Afonso Arinos teria descoberto a dimensão "pura" e "vital" do passado, dos hábitos preservados nas tradições populares e das paisagens do país. Assim, quando no Brasil, o escritor promovia uma série de conferências sobre lendas e tradições populares, realizava bailes com apresentação de danças regionais pelos "próprios nativos" (idem, ibidem, p. 238).

Por outro lado, Hermano Vianna (2002, p. 56) demonstra que Arinos nutria uma preocupação nacionalista na sua relação com os hábitos populares. O escritor não via com bons olhos o caráter regionalizado, 
Em busca de uma modernidade nacional: o movimento modernista e o projeto político-cultural do regime Vargas

fragmentado, do país, defendendo um "grande esforço no sentido da unificação moral da pátria". Para Arinos, a mistura existente entre costumes e tradições populares regionais, de certo modo, já vinha realizando essa tarefa de formação da unidade brasileira. $\mathrm{O}$ intelectual argumentava que o pouco de unidade que tínhamos, devíamos ao povo, pregando uma aliança entre elite e povo em prol da unidade nacional.

Segundo Sevcenko (1992, p. 242), a montagem da peça “O contratador de diamantes", obra póstuma de Arinos, foi um verdadeiro marco nesse período. Com um enredo que retrata o Brasil das bandeiras, a peça ganhou grande destaque pelo fato de que foi encenada por atores amadores, que vestiam as roupas da época e apresentavam um sotaque tipicamente paulista. A cena em que "pretos de verdade" dançavam a "congada" e eram observados com alegria pelos "fidalgos", foi reproduzida com euforia pelos jornalistas que elogiaram a peça por seu "realismo primitivo" e sua "atmosfera brasileira". A peça foi recebida pela crítica como a vitória de uma sociedade que reconhece o valor de sua raça e sua cultura.

A peça é heurística porque sintetiza uma fusão cada vez mais comum nas práticas e discursos desses grupos, a combinação singular dos seguintes valores: tradição colonial, cultura popular, sofisticação e distinção social (SEVCENKO, 1992, p. 244).

A partir daí, principalmente no final dos anos 10 e início dos anos 20, o que vemos é a difusão de um nativismo e de um nacionalismo cultural e político exacerbados. A literatura regionalista, os saraus caipiras, os documentários sobre o interior do país tomam conta das principais capitais. Grupos de artistas partem em expedições para as cidades históricas. Ao mesmo tempo, uma onda de propaganda nacionalista e de ativismo intelectual se propaga. As duas perspectivas se cruzam a partir da crença de que a tradição popular portava um elemento nacionalizador, capaz de promover a comunhão com a personalidade nacional.

O fim da Primeira Grande Guerra e o início dos anos 20 marcam a entrada da ordem socioeconômica mundial em uma nova fase, um período de transição que envolvia mudanças em todos os âmbitos da experiência moderna. Em primeiro lugar, o capitalismo mundial supera a fase 
expansiva e concorrencial do imperialismo passando para uma fase de acumulação intensiva, caracterizada pela verticalização da produção e das estruturas organizacionais (configurando as chamadas economias de escala), pela formação dos oligopólios internacionais, além do destacamento dos Estados Unidos como novo protagonista (ARRIGHI, 1997, p.27). Em segundo, esse novo ciclo de acumulação intensifica o processo de crescimento das cidades que se transformam em grandes metrópoles, concentrando um número inédito de contingentes humanos, principalmente de operários. Vagas humanas deslocam-se de seus territórios natais para esses novos centros. Nesses grandes centros as inovações tecnológicas criam um ambiente eufórico, a democratização do automóvel e os novos meios de comunicação em massa forjam um cenário centrado na luz e na velocidade.

Como sugere Sevcenko (1992, p. 19), essa erupção de inovações presente nas grandes metrópoles invade o cotidiano de milhões de pessoas, desestabilizando os velhos modelos geracionais, fragmentando modos de ser enraizados, corroendo todo e qualquer resquício de um mundo estável. O movimento que segue esse cenário de instabilidade, segundo Sevcenko, é uma busca incessante por novas referências, por novas origens, por qualquer tipo de substrato que sustentasse a fundação de uma nova ordem.

Tratava-se antes de criar um novo culto, uma nova fé, centrada nos impulsos puros da comunhão social e da ação. Era na emoção viva das gentes e na expressão física do seu desejo de resgatar a integridade do mundo que se encontravam as matrizes da nova crença, cuja doutrina era o desencanto geral, cujo ritual era a exacerbação das emoções coletivas, cuja esperança era a expectativa alerta da consumação histórica da epifania. (SEVCENKO, 1992, p. 170).

A guerra provoca uma reação anti-intelectualista e totalizante, cria uma obsessão generalizada por uma nova objetividade embasada no primado do corpo, da vida e da ação. Essa fome por fontes de vitalidade e pureza vai buscar respostas no inconsciente recém-descoberto por Freud, no primitivismo dos povos tribais africanos e pré-colombianos, no frenesi 
Em busca de uma modernidade nacional: o movimento modernista e o projeto político-cultural do regime Vargas

coletivo dos movimentos políticos de massa e seus novos líderes carismáticos (SEVCENKO, 1992, p. 178). O que está em jogo é a fantasia do novo, do moderno.

Os movimentos modernistas surgem na Europa durante a década de 10 como uma tentativa de conciliar a arte com esse mundo que surgia, movediço e desestruturante. Entre 1900 e 1910, Henri Matisse, Georges Braque e Pablo Picasso iniciam as experimentações que culminam na criação do cubismo, uma linguagem agressiva e analítica, que sintetiza elementos de ambiguidade, dúvida, ação e reflexão. Essa nova perspectiva artística influencia uma série de outros artistas e intelectuais, de inúmeras nacionalidades, provocando uma verdadeira revolução cultural. Contudo, o golpe da guerra fora muito profundo para que se mantivesse uma atitude generalizada de experimentação, relativismo e agressividade, o cataclismo atingiu os próprios artistas e a busca por um novo equilíbrio nas artes vai ser anunciada por dois artistas que estiveram nos campos de batalha: o poeta francês Guilaume Apollinaire e o escritor suíço Blaise Cendrars (SEVCENKO, 1992, p. 185). A mensagem era clara: era preciso encontrar um novo começo para a arte moderna, animado pelo carisma, alegria e profundidade de diferentes elementos estéticos, como a cultura popular e a arte primitiva, reunidos com o propósito de alcançar dimensões superiores, de cunho emotivo, mágico e integrador.

Desse modo, a reviravolta da guerra e a consequente busca por uma nova ordem que superasse aquele momento disruptivo chegavam até às artes. Nessa nova fase do modernismo, as composições procuram criar uma síntese instável, agregando uma diversidade de elementos estéticos com o objetivo de surpreender o público e, então, levá-lo a uma região ulterior de mágica e alegria primordial, forjada a partir de sugestões populares, exóticas, nacionais, tecnológicas, etc. Nesse momento, a utilização de elementos retirados das tradições populares e das manifestações culturais das tribos africanas e pré-colombianas não era movida apenas pelo desejo de experimentação e inovação, o interesse pelo "Outro exótico" tornara-se uma questão espiritual: o primitivismo, a vitalidade e a pureza dessas manifestações faziam com que seus elementos funcionassem como instrumentos mágicos, capazes de elevar o espectador a um nível superior de experiência. A crítica à Civilização e a busca pelo novo, pelo moderno, desdobra-se em uma fuga para um "Outro mágico". 
Enfim, a partir da guerra, a arte precisava comportar um aspecto espiritual, constituindo-se como uma espécie de artefato de salvação. Era imprescindível que as novas vanguardas artísticas contribuíssem para o alcance de um novo equilíbrio, construindo novos planos de identidade, de organicidade.

O cenário da cidade de São Paulo no início da década de 20 não estava muito distante do cenário existente nas grandes metrópoles europeias e norte-americanas. Desde a virada do século, a cidade vivia um surto de crescimento e riqueza por conta da sua posição como centro articulador da economia cafeeira. A cidade crescia em ritmo vertiginoso, expandindo-se em todas as direções, os edifícios tornavam-se cada vez mais altos, multidões tomavam a cidade, os bairros de operários e imigrantes multiplicavam-se, os automóveis assumiam as ruas, os painéis luminosos davam um novo tom para o centro, as empresas e marcas norteamericanas se instalavam na cidade, etc. A cidade assumia cada vez mais as feições de uma metrópole do século XX.

No cenário cultural, os cinemas, os teatros e os salões de dança se espalhavam pela cidade. As roupas acompanhavam as modas presentes nos filmes de Hollywood. Os jovens mais abastados participavam de corridas de carro e assistiam fascinados aos roads de aviões que cruzam os céus da cidade. A prática de esportes tornava-se cada vez mais comum. As publicações dos jornais pregavam a adoção de um estilo de vida "jovem", esportista, alinhado à última moda, com prazer e disciplina (SEVCENKO, 1992, p. 34).

Até certo ponto, o frenesi de um novo tempo, veloz e dispersivo, se espalhava pela cidade, convivendo com as reminiscências, os velhos ritmos, hábitos e paisagens, da São Paulo oitocentista. Esse aspecto híbrido condicionava, mas não impedia a propagação dos sentimentos e fantasias ligados aos diversos elementos contidos nesse "presente profético": o automóvel, o avião, a música, a moda, o esporte e as artes. Desse modo, havia um enorme interesse em promover e vivenciar tudo o que havia "de mais moderno" na cidade.

O mundo das artes em São Paulo também estava tomado pela fantasia do moderno. A prosperidade da cidade, além de subsidiar uma 
Em busca de uma modernidade nacional: o movimento modernista e o projeto político-cultural do regime Vargas

sequência contínua de exposições e apresentações locais, atraía o circuito das artes modernas mundiais, tornando frequente a presença de grupos de vanguarda europeus e norte-americanos. Jovens herdeiros das grandes famílias paulistas, como Paulo Prado e Olívia Penteado, colocavam acervos atuais e significativos à disposição dos artistas de São Paulo, influenciando toda uma geração interessada nas vanguardas modernistas. Naquele momento, as exposições de artistas brasileiros já envolvidos com as novas linguagens estéticas costumavam atrair multidões, como no caso da exposição de Anita Malfatti em 1920.

A chegada do ano de 1922, o ano do centenário da independência do Brasil, multiplicou os esforços para promoção de eventos, exposições, conferências, peças, tudo que contribuísse para a grande celebração do ano da pátria. A febre nacionalista continuava em crescente no país e certamente foi potencializada pela data: o desejo de exaltar os valores pátrios e glorificar a história nacional dava o tom dos eventos de comemoração. Acompanhando o tom nacionalista, o nativismo também estava presente nas comemorações, sobretudo, nas inúmeras atividades do movimento neocolonial. E como não poderia faltar, tudo o que estivesse ligado ao "moderno", ao presente profético da cidade, do país, e do mundo, era muito bem-vindo à programação

Incorporando toda essa atmosfera que combina vanguardas modernistas internacionais, nativismo e nacionalismo, a Semana de Arte Moderna é organizada em São Paulo por um grupo de intelectuais ligados a Paulo Prado, com o intuito de divulgar as produções mais recentes dos artistas brasileiros no campo das artes modernas, reunindo poetas, escritores, pintores, escultores e músicos.

Logo na conferência de abertura, proferida por Graça Aranha, a tônica profética, espiritual, da nova fase das vanguardas modernistas aparece como nota central. $\mathrm{O}$ escritor atribui à arte a função de transmitir emoções absolutas e promover, através dessas emoções, a unidade com "o Todo". Era preciso buscar os valores da pureza, da vitalidade, do sublime. Aranha então dispara contra as vertentes artísticas produzidas até então no país, argumentando que a arte ainda não existia no Brasil, em verdade, estava sendo fundada naquele momento (ARANHA apud SEVCENKO, 1992, p. 269).

Na abertura do segundo dia de evento, Menotti Del Picchia critica veementemente o caráter mimético e postiço das vertentes acadêmicas, 
movidas pela reprodução de estilos e perspectivas estrangeiras do século XIX. Utilizando elementos figurativos que combinam os termos do universal, do moderno e do nacional, Del Picchia propõe a formação de uma arte genuinamente brasileira, voltada para a tematização das odisseias brasileiras, célebres ou anônimas, inspirada nos diferentes elementos do cotidiano contemporâneo do país. A mensagem, prenhe de imagens ousadas, defende basicamente a constituição de uma arte que retratasse a própria modernidade nacional (DEL PICCHIA apud AMARAL, 1998, p. 278).

O programa da semana era o mais variado possível, trazendo uma série de tendências e estilos. Claramente, um dos principais objetivos da semana era, nos dizeres de Mário de Andrade, promover "uma revolta contra o que era a inteligência nacional", criticada pelos modernistas por seu "passadismo" e "europeísmo". Nesse sentido, inspirados no modernismo europeu, os participantes da semana acreditavam que era necessário realizar um esforço de atualização da arte produzida no país, renovando seus princípios e técnicas a partir das novas vanguardas. Ao mesmo tempo, influenciados pelos cenários nacionalista e nativista, bem como pelo próprio exotismo do modernismo europeu, esses intelectuais defendiam a necessidade de nacionalização da arte a partir da estilização de temas e objetos vinculados às tradições históricas, populares e regionais do país, e até mesmo de seus cenários contemporâneos.

Pode-se dizer que a fórmula do modernismo brasileiro, gestada nesse período, combina a busca por uma identificação nacional, pela respectiva projeção plástica dessa identidade, com a tarefa de renovação formal através dos princípios e técnicas desenvolvidos pelas vanguardas europeias (AMARAL, 1998, p. 23). Dessa forma, o espírito simultaneamente crítico e renovador do modernismo europeu serviria como instrumento formal utilizado na destituição de uma arte "postiça", voltada para o passado e para o estrangeiro, e na conseguinte criação de uma arte atual, moderna, autêntica e nacional.

Segundo Sevcenko (1992, p. 273), justamente pelo fato de que sua obra constituía o modelo mais bem-acabado dessa fusão entre os termos do moderno e do nacional, que o músico Heitor Villa-Lobos foi recebido como a principal atração da semana, tendo participação central no evento: todos os dias foram encerrados com a apresentação do "prodígio da nova arte brasileira". Para o autor, Villa-Lobos era a plataforma viva da nova arte, 
Em busca de uma modernidade nacional: o movimento modernista e o projeto político-cultural do regime Vargas

pois conseguira, mais do que ninguém, combinar temas e ritmos populares, formas modernas e acento nacional.

A música de Villa-Lobos era o protótipo da arte que se propunha durante a semana. O modelo estava gerado na obra do compositor, atendendo a uma série de buscas e demandas, e por isto mesmo que lhe foi dado tanta a publicidade e prestígio. $\mathrm{O}$ maestro correspondia a toda aspiração por uma síntese final entre o tradicional, o popular, o nacional e o moderno. Ele conquistara os valores proclamados pelas vogas nacionalista, nativista e vanguardista que vinham definindo o contexto intelectual da última década e, assim, foi euforicamente aclamado, recebendo convites para apresentações e uma bolsa para estudar em Paris.

Até certo ponto, tudo o que foi dito sobre a obra de Heitor VillaLobos aplica-se à Semana de Arte Moderna e aos seus principais participantes, no sentido de que esse grupo de artistas atuou como uma espécie de para-raios da atmosfera cultural existente no país. Apesar da variedade de tendências expostas e do fato de que ainda não havia uma perspectiva bem definida, não deixa de ser verdade que a concepção de arte ali proposta incorporava: o esforço de formação de uma inteligência nacional, pregado pelo nacionalismo intelectual; o interesse quase religioso por temas e objetos das tradições populares e regionais, legítimos portadores de um espírito autêntico e nacional, como proposto pelo nativismo e pelo próprio exotismo modernista europeu; e, finalmente, a tentativa de combinar tudo isto com uma perspectiva moderna, inspirada nas inovações e linguagens desenvolvidas pelas vanguardas europeias e que fosse condizente com o novo ambiente de mudanças que tomava conta do mundo, do país e daquela metrópole.

Se o modernismo é considerado por muitos como um ponto de referência, é porque este movimento cultural trouxe consigo uma consciência histórica que até então se encontrava de maneira esparsa na sociedade (ORTIZ, 2006, p.40).

Não devemos pensar em "consciência histórica" como um ato deliberado que procura sintetizar pensamentos até então difusos. O modernismo brasileiro foi influenciado por todas essas tendências culturais, bem como pelo cenário de transformações vivido pela cidade, 
pelo país e pelo mundo, incorporando um conjunto de valores e perspectivas que estimularam uma trajetória de busca, mais ou menos consciente, na direção de uma síntese entre o popular, o nacional e o moderno.

Um momento crucial dessa trajetória foi quando, dois anos após a Semana, vários artistas do movimento se instalaram em Paris para iniciar uma série de pesquisas sobre as novas vanguardas europeias, experimentando as linguagens modernistas in loco. Além de Villa-Lobos que já estava estudando em Paris e alcançara um tremendo sucesso na capital francesa, Brecheret, Anita Malfatti, Tarsila do Amaral, Di Cavalcanti, Rego Monteiro, Oswald de Andrade e muitos outros compunham o grupo que lá chegou em 1924.

Como dissemos, a capital francesa vivia uma onda de exotismo, uma verdadeira paixão pelo "Outro mágico". Boa parte dos demais artistas brasileiros instalados em Paris sofre um impacto imediato por conta de todo esse interesse e valorização das manifestações populares e autóctones vindas de outras partes do mundo.

O período, caracterizado pela experimentação das vanguardas modernas in loco e pela intensificação do interesse nativista nos artistas modernistas, ainda foi marcado pela viagem de "redescoberta do Brasil", na qual um grupo de artistas brasileiros, como Oswald de Andrade, Mário de Andrade e Tarsila do Amaral, acompanharam o escritor suíço Blaise Cendrars em uma viagem ao Rio de Janeiro e às cidades históricas de Minas Gerais.

Do ponto de vista de Mário, Oswald e Tarsila, a viagem foi uma verdadeira revelação das raízes históricas, étnicas e culturais que eles tanto buscavam para então combinar à nova linguagem artística. A partir dessa experiência, os poetas e a pintora intensificam a tentativa de fundir as linguagens modernas com a temática nacional, recuperando as imagens daquela viagem de descoberta do Brasil (AMARAL, 1998, p. 34). É justamente nesse momento que Oswald vai publicar o Manifesto PauBrasil, anunciando a luta entre a "arte de importação" e a "arte de exportação", reivindicando a propagação de uma arte prenhe de brasilidade. E Mário vai desenvolver poesias nas quais procura compor símbolos e representações nacionais.

A partir de então, os principais representantes do movimento vão se envolver cada vez mais com a missão de realizar a "independência" da arte 
Em busca de uma modernidade nacional: o movimento modernista e o projeto político-cultural do regime Vargas

brasileira, de modo que a opção pelo nacional vai se tornando cada vez mais preponderante. Como sugere Sevcenko (1992, p. 299), o Manifesto Antropofágico de Oswald de Andrade é bem evidenciador desse momento de radicalização do movimento. O manifesto é um grito de ordem em favor do "reabrasileiramento" do Brasil a partir de uma origem pura e autêntica, destituindo as heranças lusitanas artificiais. Já Mário de Andrade defendia que o nacionalismo estético era necessário apenas em um primeiro momento de constituição da arte nacional. Pautado nessa perspectiva, o autor procura obter em seus textos uma síntese coerente do Brasil, revelando uma preocupação de cunho popular e nacional.

O elogio do "verdadeiro Brasil" torna-se cada vez mais central, propagando o processo de valorização do popular como nacional, de modo que esta seria a tônica durante toda a década de 30. Apesar de em algum momento criticar e se afastar da perspectiva dos modernistas paulistas, Gilberto Freyre vai ser responsável pela criação da forma mais acabada dessa perspectiva, enterrando o pessimismo racial de 1870 e alçando o mestiço como o cerne vigoroso dessa nova identidade nacional (VIANNA, 2002, p. 78).

De certa maneira, o movimento modernista conquista espaço importante no âmbito das artes plásticas e da literatura brasileira ao longo da década de 20, entrando na década de 30 com um posicionamento de destaque no âmbito da produção cultural brasileira. $O$ caráter bemsucedido do movimento estava diretamente vinculado ao modo como ele conseguiu catalisar as perspectivas do cenário cultural brasileiro, propondo uma linguagem que captava valores em alta naquele contexto: modernidade, atualidade, nacionalismo, autenticidade, tradição nacional, cultura popular, etc.

Em 1942, Mário de Andrade profere uma conferência sobre o movimento, argumentando que os três princípios básicos do projeto modernista eram: "o direito permanente à pesquisa estética, a atualização da inteligência brasileira e a estabilização de uma consciência criadora nacional (ANDRADE, 1972). Imbuídos por esse projeto, o grupo então se destaca pela sua familiarização com as vanguardas artísticas mais atuais da época e pela propagação de uma nova linguagem artística no país. Simultaneamente, se lançam na tentativa de explorar e conhecer o Brasil, se legitimando, pouco a pouco, como portadores de um valioso saber sobre os costumes populares e tradições regionais do país. Finalmente, procuram 
realizar a síntese máxima desses esforços, constituindo uma arte, ao mesmo tempo, moderna e nacional. Uma linguagem que se diz atual, autêntica e brasileira e que, ao se inspirar na fase mística do modernismo europeu e ser influenciada pelo nacionalismo e pelo nativismo em voga no país, procura se constituir como uma nova expressão cultural capaz de captar e reproduzir o próprio espírito da nacionalidade.

Em suma, os modernistas direcionam a sua trajetória no sentido da autoconstituição enquanto inteligência nacional e, ao conseguir captar valores e anseios em alta, acabam se destacando naquele momento e nas décadas seguintes.

Para os nossos propósitos, o mais importante é perceber que a perspectiva preconizada pelo movimento modernista tomava a nação como um pressuposto e, simultaneamente, concebia a arte como um meio de expressar e entrar em contato com a mesma. Contudo, essa perspectiva não se desdobrava em uma postura romântica ou primitivista, afinal, havia pleno interesse em harmonizar esse elemento nacional com o espírito moderno. A tentativa de criação de uma expressão autêntica, que partisse desse subterrâneo nacional, estava o tempo todo sintonizada com a tentativa de adequá-la ao novo e ao atual.

Nos discursos e práticas desses intelectuais, é evidente a crença compartilhada que toma as múltiplas variedades do popular e do tradicional como manifestações de uma mesma entidade nacional. Como afirma Daniel Pécault (1990, p. 47), essa geração de intelectuais acreditava na existência de um vínculo social não-político que unia diferentes indivíduos e segmentos sociais, compondo uma nação brasileira ainda latente. Esse "espírito nacional" estaria presente na heterogeneidade das manifestações populares, não apresentando, até aquele momento, uma expressão consciente e unívoca.

A crítica ao academicismo e ao "europeísmo", vigentes até então, pautava-se em uma recusa de tudo o que fosse postiço, artificial. A conseguinte busca por pureza e autenticidade acaba fundindo-se com o imaginário nacionalista, tomando o popular, o mestiço, o tradicional, ressignificados a partir dos anos 10, como uma espécie de "substância nacional" produzida por uma entidade não manifesta. De certa forma, o que estava sendo formado ao longo de todo esse período era uma espécie de estatuto simbólico que definia o que representava e o que não representava esse "espírito nacional". Em suma, o que era ou não 
Em busca de uma modernidade nacional: o movimento modernista e o projeto político-cultural do regime Vargas

propriamente brasileiro. Assim, diversos elementos ligados aos costumes e tradições populares receberão o status de componentes de uma identidade nacional latente.

A partir do momento em que se propõe a explorar e desvendar os "alicerces da nacionalidade brasileira", para então produzir uma arte capaz de expressar essa nacionalidade, o movimento modernista se posiciona como uma espécie de "intérprete" e "porta-voz" da nação. Nesse sentido, como sugere Daniel Pécault, esse grupo definia sua posição artísticointelectual a partir da posse de um saber legítimo sobre o social: eles detinham o conhecimento e o meio necessários para captar e interpretar os sinais de uma nação inscrita na realidade, mas ainda desprovida de expressão cultural organizada (PÉCAULT, 1990, p. 38). Ora, na sua visão, não seria a arte nacional por eles concebida, o próprio modelo dessa expressão cultural organizada?

Em última medida, esses intelectuais se viam envolvidos na tarefa de recolher os fragmentos da cultura popular para, então, fazer dela a base de uma cultura nacional (PÉCAULT, 1990). Todo o seu esforço estava direcionado para a fusão de toda uma amalgama de manifestações culturais em torno de uma única expressão cultural, a nacional. Desse modo, a tarefa de unificação moral da pátria atribuída à classe culta por Afonso Arinos, estava em plena execução.

Como analisado, ainda por Daniel Pécault, o grupo modernista faz parte de uma geração de intelectuais que se atribuía a missão de formar uma consciência nacional. Na sua perspectiva, era preciso formar uma literatura, uma arquitetura, enfim, uma arte brasileira que contribuísse para o advento de uma identidade cultural nacional (PÈCAULT, 1990, p. 38). Esse grupo de intelectuais pretendia fomentar as condições necessárias para o surgimento desse "espírito nacional" oculto enquanto vontade coletiva, em suma, enquanto entidade cultural e politicamente organizada. Justamente por estarem munidos das ferramentas teóricas e estéticas necessárias para o desvendamento das expressões culturais, dos pensamentos e sentimentos dos povos brasileiros, esses artistas e intelectuais creditavam a si mesmos uma espécie de vocação nacional (PÈCAULT, 1990, p. 52).

Em torno do imperativo nacional, organizou-se assim um universo de debates políticos que, 
manifestando divisões, mas também consenso em torno de um mesmo objetivo, conferia aos membros da elite intelectual a possibilidade de um reconhecimento mútuo baseado nessa mesma vocação (PÈCAULT, 1990, p. 41).

Ao mesmo tempo em que o grupo modernista incorporava essa missão nacional, identificando-se como detentor de um saber sobre o popular e o tradicional que o autorizaria a construir a cultura nacional, ele também reivindicava uma postura cosmopolita, sobretudo, o alinhamento com relação aos tempos modernos.

O primeiro aspecto dessa reinvindicação cosmopolita está contido no reconhecimento das novas linguagens artísticas europeias como paradigma da arte moderna. Até certo ponto, na visão dos modernistas a adoção daquele paradigma era inevitável, pois ele constituía o meio através do qual a arte nacional estava sendo criada. Afinal, o modernismo europeu na sua fase "espiritual" se propunha como porta de entrada para uma dimensão superior, a emoção, e o que os modernistas brasileiros estavam criando era justamente uma porta de entrada para o "espírito nacional".

Por outro lado, havia um enorme interesse em tematizar e incorporar elementos do mundo moderno, bem como do cenário contemporâneo da cidade de São Paulo e do país como um todo. É nesse sentido que Menotti Del Picchia fala da necessidade de representar o cowboy nacional de Rio Preto, o sonho de Ícaro realizado por Edu Chaves, a cidade tentacular de 600 mil almas. O olhar para o nacional não implicava um olhar romântico para o passado e para a tradição, mas o cruzamento de diversas temporalidades a partir de uma perspectiva atual, ou mais especificamente, moderna.

Por último, essa reinvindicação cosmopolita também se desdobrava na adoção de uma postura crítica, "destrutiva" e, simultaneamente, renovadora. O movimento surgiu como uma forma de interrogar e desestabilizar perspectivas vigentes, destituindo estilos e posturas rotulados como "anacrônicos" para, então, construir um projeto de renovação cultural que fosse, acima de tudo, moderno.

A nosso ver, a linha de articulação entre a utopia artística modernista e a ideologia do regime Vargas está contida justamente no modo bem-sucedido como o projeto modernista articulou o apelo pelo 
Em busca de uma modernidade nacional: o movimento modernista e o projeto político-cultural do regime Vargas

moderno e o imperativo da nacionalização. Em certa medida, a concepção cultural modernista estava sintonizada com dois aspectos muito caros ao desenvolvimento da proposta política do regime: primeiro, a necessidade de adaptar-se e, em seguida, estimular o cenário de inovação socioeconômica; segundo, a tarefa de configurar uma consciência nacional que fosse a base de ação de um Estado cada vez mais intervencionista (ou seja, havia a necessidade de ser eficaz na regulação das condutas).

Não se trata de cooptação política de um modelo cultural "pronto", porque este combina modernidade e nacionalismo. Obviamente, o valor público e simbólico dos intelectuais modernistas e de sua obra "genuinamente" nacional contava muito para aquela elite política. Mas muito mais decisivo do que isso, era o fato de que os dois grupos compartilhavam um pequeno, mas relevante, conjunto de perspectivas, princípios, valores e aspirações. Provavelmente, um dos principais pontos de contato estava na missão de constituição da nação que os dois grupos assumiram. Por outro lado, a auto identificação como construtores de um novo equilíbrio, de uma nova harmonia que fosse a encarnação de uma modernidade nacional, certamente influenciou nesse cruzamento.

2. Mediações entre modernismo e projeto político-cultural do regime Vargas

A revolução de outubro de 1930, que marca o início da chamada "Era Vargas" no Brasil, esteve ligada a um conjunto de fatores de ordem política, econômica e social. Apesar de ter sido capitaneada por líderes de oligarquias estaduais injuriados com a eleição do candidato paulista Júlio Prestes, a revolta obteve apoio de diversos segmentos sociais que estavam insatisfeitos com os governos da Primeira República por uma série de aspectos políticos e extra políticos. Dentre eles, parte dos próprios cafeicultores que estavam ressentidos com o fim da política protecionista do governo federal, os jovens oficiais ligados às revoltas tenentistas, as chamadas classes médias urbanas, além de diversas facções intelectuais (OLIVEIRA, 1980, p. 42).

Os primeiros anos do regime Vargas foram caracterizados pela tentativa de conciliação dos interesses e demandas desses diversos grupos. Durante todo o governo provisório, esses grupos procuraram influenciar Vargas para que adotasse uma ou outra proposta política, enquanto o 
presidente tentava sinalizar em favor de todos eles (SKIDMORE, 2010, p. 47).

Contudo, ao longo de toda a década de 30, o novo regime apresenta uma tendência crescente no sentido da proposta autoritária dos tenentistas. É bem verdade que Getúlio mantinha uma relação restrita com esse grupo, mas o seu governo caminhava cada vez mais no sentido da centralização e fortalecimento do poder federal. Pouco a pouco, o executivo federal vai absorvendo o sistema decisório, expandindo a sua máquina burocrática em todos os setores e níveis, construindo suas próprias mediações políticas e sociais, além de utilizar diversos estratagemas para desestruturar as bases políticas regionais. Como apontado por Diniz (1996, p. 114), a expansão burocrática contribuía para a diversificação das instâncias de negociação e absorção de demandas. Desse modo, o processo de expansão desdobravase na formação de uma estrutura de comando capaz de atender aos interesses dos diversos grupos que apoiavam o regime.

Ao longo do seu desenvolvimento político, o regime Vargas vai tornando cada vez mais evidente o seu intenso esforço no sentido de constituir um comando concentrado e ao mesmo expansivo, capaz de funcionar como mediador político, econômico e social privilegiado.

A radicalização do cenário político com o fortalecimento dos movimentos de massa de esquerda (Aliança Nacional Libertadora) e de direita (Ação Integralista) criou uma série de oportunidades para que Vargas fortalecesse o poder central através de contínuos estados de sítio (SKIDMORE, 2010, p. 54). O cenário de tensão acaba culminando no golpe de 1937 e no início da ditadura estado-novista.

Olhando bem, a perspectiva de longo prazo sugere que o golpe era apenas a confirmação e o Estado Novo a conseguinte intensificação de um modelo centralizador e autoritário que já vinha sendo ensaiado. A ingerência do executivo federal nas mais diversas áreas é um indício muito forte nesse sentido. O desenvolvimento da ação estatal, sobretudo do executivo federal, revela um profundo interesse em instaurar solidariedades políticas e sociais verticais, expandindo a capacidade de regulação do Estado sobre diversos setores e segmentos.

Analisaremos o desdobramento ideológico desse esforço de integração vertical, bem como sua relação com o âmbito cultural. Contudo, nesse momento, não podemos deixar de levar em conta a importância que 
Em busca de uma modernidade nacional: o movimento modernista e o projeto político-cultural do regime Vargas

o cenário socioeconômico teve no desenvolvimento do novo regime político e, consequentemente, nas suas perspectivas ideológica e cultural.

Assim que Vargas assume o comando do governo provisório em 1930, um dos primeiros problemas que teve de solucionar foi o cenário de deterioração do comércio externo brasileiro. A crise de 1929 provocou uma forte retração dos recursos financeiros disponíveis na economia internacional e, como o governo federal vinha adotando uma política financeira ortodoxa, o setor cafeeiro e o governo paulista não foram capazes de impedir uma vertiginosa queda do preço de café com a chegada de mais uma super safra entre 1928 e 1930. A forte queda nas divisas produzidas pelo setor exportador, combinada com um período de retração dos fluxos internacionais, resultou em uma drástica escassez de reservas de ouro e divisas. As consequências negativas eram inúmeras (ABREU, 1996, p. 17).

A própria capacidade de funcionamento da economia, bem como do próprio Estado, estava comprometida. Desse modo, o novo governo adotou, de modo experimental e rudimentar, algumas medidas para solucionar a crise (ABREU, 1996, p. 24).

O conjunto de medidas cambiais e fiscais, além de solucionar a crise externa, contribuíram para a intensificação do processo de substituição de importações. Ao longo da década de 30, o país vive um intenso processo de industrialização extensiva, com forte crescimento da produção nacional de bens não duráveis e a consequente redução da pauta de itens de importação.

A percepção de que essas medidas tornavam o país menos dependente dos ciclos econômicos internacionais, reduzindo a vulnerabilidade de satisfação das demandas internas, leva o regime Vargas a empreender, pouco a pouco, uma política articulada de estímulo e fomento à produção nacional, preocupando-se também com a expansão e integração do mercado interno do país. Já nos anos 40, a política de industrialização passa a ser vista como uma questão de defesa militar e soberania nacional, desdobrando-se em um discurso e uma forte propaganda nacionalista por parte do regime Vargas (SKIDMORE, 2010, p. 78).

Desse modo, a capacidade de controle eficaz do curso da economia vai se tornando uma necessidade política do regime que, então, passa a empreender uma política econômica cada vez mais intervencionista. Era 
muito importante evitar os desgastes provocados por flutuações e, consequentemente, era preciso direcionar o processo em prol da autonomia econômica do país. Esse vai ser um dos motivos que levam o regime a transferir para dentro do Estado um conjunto de segmentos engajados no projeto de industrialização e modernização do país, como empresários e intelectuais.

Em suma, é nesse sentido que Vargas vai levantar em 1937 a bandeira da necessidade de se criar um Estado forte capaz de orientar as transformações socioeconômicas. Ou seja, esse cenário contribui para uma crescente autoproclamação do Estado como guia e construtor de um novo Brasil, um Brasil industrializado e independente economicamente.

A partir das devidas considerações sobre a evolução política e econômica do regime Vargas, o que notamos é que, ao longo dos anos, o novo regime vai tomando a forma de um Estado autoritário e centralizador, apoiado em dispositivos burocráticos e administrativos que se espalham por todos os âmbitos, com o objetivo de viabilizar um comando concentrado e, ao mesmo tempo, bem disseminado. Como aponta Skidmore (2010, p. 67), por mais que não fosse obra dos tenentistas, o Estado Novo era a própria materialização do modelo proposto por eles: um organismo centralizado e forte que se auto legitima através da missão de organização da nação, procurando constituir-se como construtor privilegiado de mediações sociais e políticas verticais.

Lúcia Lippi demonstra como esse processo foi desenvolvido sob a égide da ideologia do interesse geral. Segundo a autora, esse discurso ideológico procurava legitimar a ação do Estado identificando-o como promotor dos interesses de um todo orgânico e indivisível, a nação (OLIVEIRA, 1980, p.42). No discurso de posse de 1937, Vargas justifica a iniciativa do golpe como medida necessária para manter a nação integrada, evitando que a tendência anárquica dos interesses privados tomasse conta do Estado em um momento crucial. $O$ Estado não representa os diversos interesses que circulam na arena política, mas a própria entidade nacional. Boa parte das ações do Estado são legitimadas pelo imperativo de integrar a nação, de promover a unidade e o equilíbrio entre as classes.

Por outro lado, a necessidade e o respectivo esforço de controle eficaz dos processos de transformação socioeconômica, levam o regime a assumir cada vez mais a bandeira da renovação econômica do país em favor de sua independência. Principalmente na virada das décadas de 30 e 
Em busca de uma modernidade nacional: o movimento modernista e o projeto político-cultural do regime Vargas

40, o Estado Novo procura se identificar como promotor do processo de crescimento econômico através da industrialização e responsável pelo desenvolvimento de uma economia doméstica menos vulnerável, trunfo da emancipação econômica do país.

Dois desdobramentos desses processos foram decisivos para a articulação entre modernismo e regime Vargas que nos propomos a analisar nesse capítulo.

Em primeiro lugar, o esforço de centralização e expansão dos dispositivos de regulação, animado por uma ideologia do interesse geral, trouxe consigo uma preocupação contínua por parte do regime no sentido da formação de uma consciência nacional (sobretudo, na sua forma patriótica e cívica). Não é possível determinar até que ponto essa preocupação fazia parte, por um lado, de uma perspectiva que tomava o povo-nação como matéria amorfa desprovida de consciência política ou, por outro lado, de uma necessidade de legitimar e tornar eficaz a penetração do novo regime. É possível que as duas coisas. De qualquer modo, o que interessa para a nossa análise é o fato de que o regime Vargas desenvolveu uma política educacional e cultural contínua com o objetivo de criar essa consciência nacional.

Os órgãos envolvidos nessa tarefa apoiaram-se intensamente nos novos meios de comunicação em massa, principalmente no rádio, com o intuito de conformar formas de afetividade e memória nacional que configurassem parte dessa consciência. Sinceramente, não é possível determinar até que ponto essa política se deu de maneira deliberada e consciente, mas o fato é que alcançou um alcance extraordinário, sobretudo, com o espaço aberto criado para novas sínteses a partir do desenraizamento simbólico parcial sofrido por inúmeros contingentes deslocados para as grandes metrópoles.

Obviamente, esse esforço tinha como contrapartida a constituição de um mosaico de estilos e tendências artístico-culturais que, a partir de então, tornar-se-iam representantes diletos da "cultura nacional". Como não poderia deixar de ser, o reconhecimento como detentores de um saber autorizado vai garantir que diversas facções intelectuais trabalhem na construção desse edifício cultural comum².

2 Quando falamos da construção de um edifício cultural comum com contribuição dos intelectuais, não queremos dizer que o processo de 
Esse certamente foi o principal ponto de comunicação existente entre as atividades do grupo modernista e o regime Vargas. Mas não podemos deixar de considerar o segundo desdobramento que tomamos como fundamental para a nossa análise. A nosso ver, a progressiva identificação do regime Vargas como guia dos processos de transformação socioeconômica e promotor do novo Brasil repercutiu em três aspectos.

Primeiro, o Estado assume uma perspectiva de aliança e mesmo absorção dos grupos envolvidos com a missão de modernização do país nos mais diversos âmbitos, dentre eles intelectuais e artistas. De certo modo, o regime Vargas reatualiza a relação entre Estado e ciência, nesse momento reengendrada em prol da industrialização e soberania do país:

...uma vez que o Estado brasileiro se legitimava por uma dupla aptidão - a de se adaptar às leis que presidem a evolução do real, e a de promover uma racionalidade que orientasse o desenvolvimento econômico e gerasse as relações sociais -, ele conferia à ciência o estatuto de componente primordial da política e, simultaneamente, aos 'intelectuais' o de protagonistas privilegiados da vida política. Estado e intelectuais estavam mutuamente comprometidos (PÉCAULT, 1990, p. 73).

nacionalização de manifestações artístico-culturais foi controlado e concebido de maneira totalmente racional e deliberada pelo Estado e pelos intelectuais. $\mathrm{O}$ cenário é muito mais complexo, pois envolvia: primeiro, a formação de um estatuto de pureza e autenticidade ligado à crença dos intelectuais e provavelmente dos próprios gestores de que as manifestações populares e tradicionais eram portadoras de um espírito nacional, de modo que é muito difícil afirmar que a escolha de uma ou outra manifestação na composição de um "mosaico nacional" se deu de modo calculado; segundo, o modo como determinadas manifestações ganham destaque nesse processo é muito difícil de ser mensurado, pois envolve uma série de trajetórias e cruzamentos históricos que escapam à vontade do Estado e dos intelectuais (o caso do samba é muito singular, pois a valorização do ritmo musical envolve uma complexa relação entre intelectuais e músicos populares que vinha desde a década de 20). 
Em busca de uma modernidade nacional: o movimento modernista e o projeto político-cultural do regime Vargas

Segundo, o Estado se preocupa em promover e trazer para perto de si todo tipo de símbolo ligado ao progresso, à inovação, à modernização nacional (incluindo aí, obras e realizações artístico-culturais). Esse tipo de interesse foi muito importante para o destacamento da arquitetura modernista como vanguarda "oficial", pois o governo federal e, sobretudo, o governo de Minas Gerais tomaram todas as medidas necessárias para difundir a imagem e o valor dessa vertente arquitetônica.

Terceiro, o esforço de constituição de uma consciência nacional estava ligado ao discurso varguista do "novo homem brasileiro", uma tentativa de construir uma nova imagem do tipo nacional, sobretudo, a partir de uma ideologia do trabalho. Como sugere Renato Ortiz, havia um profundo interesse do regime em erigir o trabalho como valor fundamental da nova sociedade, de modo que era fundamental suprimir a imagem da "indolência e da preguiça" lançada sobre o brasileiro há muito, para construir uma figura mais compatível com a reorganização econômica e social do país (ORTIZ, 2006, p. 43). Esse esforço de formação de uma nova imagem do tipo nacional e de uma correspondente mentalidade também contou com a colaboração dos intelectuais, nesse caso, principalmente das facções católicas.

Para realizar a tarefa de constituição de uma consciência nacional, o regime Vargas se propõe a empreender um grande projeto educativocultural que visa à formação de mentalidades compromissadas cognitiva e afetivamente com os valores de uma nação em construção. Assim, o Estado cria uma série de aparatos culturais e, principalmente, educacionais destinados a produzir e difundir esses valores. O primeiro ministro da educação do regime e um dos principais ideólogos do Estado Novo, Francisco Campos, concebia esse projeto como uma missão pedagógica na qual deveriam ser incutidos símbolos, mitos e rituais em toda a população, com atenção especial para os jovens, garantindo eficácia na tarefa de condução das massas (PEREIRA, 1997, p.65).

Segundo Simon Schwartzman, esse projeto educativo-cultural estava integralmente sintonizado com a missão de integração nacional assumida pelo regime. Ao se auto proclamar como realizador do ideário da 
nacionalidade, o Estado assumia como objetivo a conformação da nação como uma entidade moral coesa. Nesse sentido, esse projeto educativocultural configurava, antes de qualquer coisa, um enorme esforço no sentido da "homogeneização da cultura, dos costumes, da língua e da ideologia" (SCHWARTZMAN, BOMENY \& COSTA, 2000, p. 182).

Ora, esse esforço de homogeneização passa diretamente pelo processo de nacionalização de determinados ritmos, costumes e tradições. Como dissemos, esse processo de nacionalização não é totalmente deliberado e controlado ${ }^{3}$, mas o fato é que o regime Vargas empreendeu todo um trabalho de composição de uma "cultura nacional", que nada mais era do que um mosaico de distintos estilos e tendências que agora se destacavam sob o rótulo do "nacional".

Não foi escolhido um dos antigos modelos regionais para simbolizar a nação, mas desses modelos foram retirados vários elementos (um traje de baiana aqui, uma batida de samba ali) para compor um todo homogeneizador (VIANNA, 2002, p. 61).

A tarefa de formação do sentido de nacionalidade passa pela constituição de uma unidade cultural nacional e, desse modo, envolve o recurso a uma série de manifestações culturais visando à finalidade nacional. Parafraseando Daniel Pécault, era preciso dar forma à matéria e, nesse contexto, os intelectuais não só detinham o segredo das formas, como da própria matéria. Ora, os intelectuais além de serem reconhecidos como grupo habilitado a conceber um projeto de linguagem capaz de sintetizar múltiplos elementos, também vinham se destacando como grupo capaz de

3 Analisando o processo de nacionalização do samba carioca, Hermano Vianna mostra em detalhes sua extrema complexidade. Trata-se de uma série de cruzamentos históricos e biográficos que vão, pouco a pouco, destacando uma determinada manifestação até que o Estado, informado por uma série de motivos e interesses, oficializa através de suas ações essa manifestação como nacional (VIANNA, 2002, p. 120). Nem sempre a presença do Estado se faz necessária para tal, mas ela é sempre um importante catalisador. Também há de considerar a ampliação de uma esfera da cultura voltada para audiências cada vez maiores. O desenvolvimento desse mercado de bens simbólicos ampliado também é decisivo para a nacionalização de manifestações culturais.

Latitude, Vol. 9, nº 1, pp. 133-170, 2015 
Em busca de uma modernidade nacional: o movimento modernista e o projeto político-cultural do regime Vargas

interpretar e acessar o "espírito nacional", principalmente, no que diz respeito aos subterrâneos do popular e do tradicional.

Como analisamos no tópico anterior, desde a década de 10, os intelectuais brasileiros assumiram uma espécie de vocação nacional. Esse aspecto aparece em Afonso Arinos e nos modernistas combinado com um verdadeiro mergulho nas tradições e costumes populares e regionais do nosso país, uma tentativa de entrar em contato e explorar o substrato nacional. Na década de 30, o novo regime acaba por reconhecer sua função enquanto exploradores dos alicerces da nacionalidade, envolvendo-os na construção de uma identidade cultural nacional.

O Estado, apresentando-se como responsável pela identidade cultural brasileira, desejava realizar a unidade orgânica da nação e recorreu aos intelectuais para alcança-la. (PÉCAULT, 1990, p. 59)

Interessado em promover esse esforço de unificação cultural, coordenando os intelectuais em favor do seu projeto educativo-cultural, o regime Vargas expande sua máquina burocrático-administrativa no âmbito da produção artístico-cultural, criando associações profissionais, apoiando e patrocinando diversos grupos, etc. O Ministério da Educação e Saúde exerceu uma importante função enquanto órgão estratégico de intervenção e absorção dos interesses e demandas relativos ao campo artístico-cultural.

... o regime Vargas se diferencia sobretudo porque define e constitui o domínio da cultura como um negócio oficial, implicando um orçamento próprio, a criação de uma intelligentsia e a intervenção em todos os setores da produção, difusão e conservação do trabalho intelectual e artístico (MICELI, 1979, p. 131).

Da parte dos intelectuais, as modalidades de participação no regime foram as mais diversas. Alguns assumiram a função de ideólogos do regime, principalmente as facções autoritárias e católicas, concebendo parte do próprio projeto educacional-cultural. Outros ocuparam funções no Estado, sem assumir uma relação simbiótica com a visão do regime, mas 
contribuindo de diversas maneiras, como no caso de Carlos Drummond de Andrade, chefe de gabinete do Ministério da Educação. Finalmente, outros se aventuram na pesquisa das manifestações populares e tradicionais, fazendo sugestões ou pedidos quando oportuno, como foi o caso de Mário de Andrade no Instituto do Livro.

Nesse sentido, forma-se toda uma rede de interdependência entre grupos intelectuais, instituições e órgãos burocráticos, direcionada para o projeto de constituição de uma identidade cultural e uma respectiva consciência nacional. Levantando novamente o argumento de Daniel Pécault, essa articulação de esforços pela constituição de uma unidade cultural decorre da mescla entre os âmbitos da produção cultural e da prática estatal, de modo que as estratégias perpetradas pelos diversos atores são motivadas por registros relativos aos dois âmbitos. Como já foi dito, há um ponto de intersecção criado por perspectivas e olhares compartilhados que, nesse caso, estão reunidos em torno de uma mesma vocação nacional. Cultura e política são termos inseparáveis no quadro do nacionalismo (PÉCAULT, 1990, p. 89).

A atuação dos centros articuladores dessa rede de interdependência, o Ministério da Educação e Saúde e o Departamento de Propaganda e Imprensa, é bem heurística para entendermos a proposta cultural do regime Vargas e a maneira como as estratégias intelectuais e políticas estão entrecruzadas nessa figuração.

Evidentemente, toda a ação do MES e do DIP esteve voltada para a constituição da consciência nacional. O principal esforço nessa direção foi empreendido através da formação de um conteúdo escolar nacionalizado e a imposição de um padrão único para todo o sistema escolar do país (SCHWARTZMAN, BOMENY \& COSTA 2000, p. 157). A atuação educacional dos órgãos responsáveis esteve toda direcionada para a tentativa "de fazer do catolicismo e do culto dos símbolos da pátria" o fundamento mítico-afetivo do novo regime, com forte contribuição dos intelectuais católicos (SCHWARTZMAN, BOMENY \& COSTA 2000, p. 97).

Além da área educacional, também foi empreendido um esforço contínuo em favor do desenvolvimento de vertentes artísticas, musicais e literárias nacionais, com amplo apoio para intelectuais e artistas que, de algum modo, haviam conquistado o selo do nacional. Através da reunião dessas vertentes sob o estatuto do nacional, o Estado Novo procurou de modo mais ou menos deliberado conformar uma síntese nacional de 
Em busca de uma modernidade nacional: o movimento modernista e o projeto político-cultural do regime Vargas

elementos culturais. Como dissemos, a revalorização do popular como portador do nacional fez com que a heterogeneidade de manifestações e tradições reconhecidas como populares concorressem como matéria-prima crucial para essa síntese, ao tempo que os intelectuais e artistas modernistas cumpriram, direta ou indiretamente, importante papel na triagem desse "material".

Schwatzman demonstra como havia um cuidado extremo por parte do ministério e do órgão de propaganda no sentido de garantir a penetração contínua da influência cultural do Estado sobre a população, principalmente através dos novos meios de comunicação em massa. $\mathrm{O}$ uso da radiofonia era visto como um meio estratégico para promoção da integração nacional, de modo que Vargas chega a defender em mensagem ao congresso a necessidade de que fossem instalados rádio receptores com alto-falantes em todas as cidades do país, "facilitando a todos os brasileiros (...) toda sorte de notícias tendentes a entrelaçar os interesses diversos da nação" (VARGAS apud VIANNA, 2002, p. 110).

Como demonstrado por Hermano Vianna, a Rádio Nacional adotava uma programação de música popular, tornando-se a emissora mais influente do regime Vargas. $\mathrm{O}$ autor também aponta para a presença da música popular no próprio programa A hora do Brasil, que até hoje tem transmissão obrigatória e divulga as notícias do Estado (VIANNA, 2002, p. 110). A radiofonia foi um instrumento muito eficaz na promoção e difusão dos ritmos musicais eleitos para compor a síntese da cultura nacional, contribuindo de forma decisiva para a criação de uma memória afetiva musical de cunho nacional. Outro indício muito interessante revelado por Vianna diz respeito à política contínua de apoio oficial e extraoficial ao samba e ao carnaval. As escolas de samba eram convidadas a representar a cultura nacional em todo e qualquer encontro internacional.

Provavelmente, o ponto de contato mais importante entre intelectuais e Estado novo foi a gestão do ministro Gustavo Capanema (1934-1945). O ministro manteve um intenso convívio, amizade e colaboração com intelectuais de diferentes facções, buscando superar as divergências ideológicas e evitando definições categóricas. Segundo Pereira (1997, p. 67), o ministro tinha considerável liberdade de ação e proposição porque estava ligado à poderosa base política de sustentação do regime em Minas Gerais, além do fato que a pasta não era objeto de constante atenção por parte de Vargas. 
Seu chefe de gabinete era um velho colega do grupo intelectual do qual fizeram parte em Belo Horizonte, o poeta modernista Carlos Drummond de Andrade. Descrevendo a atuação do ministro, Drummond afirmaria que:

“Capanema foi no MEC uma usina de ideias que se tornaram realidade. Varreu a rotina e implantou novas formas de educar e civilizar o homem brasileiro. Foi o ministro que deu maior atenção às renovações artísticas..." (ANDRADE apud SCHWARTZMAN, BOMENY \& COSTA, 2000, p. $44)$.

Apesar do relato exagerado de um velho colega, o fato é que as vanguardas modernistas tiveram amplo acesso ao espaço do ministério. Destrinchando a pesquisa de Simon Schwartzman sobre a gestão do ministro (SCHWARTZMAN, BOMENY \& COSTA, 2000), notamos que pelo menos três grandes expoentes do modernismo mantiveram uma relação estreita e profícua com o ministro: Mário de Andrade elaborou o projeto que culminaria na criação do Serviço de Patrimônio Histórico e Artístico Nacional, além de ter ocupado cargo de chefe de seção dentro do Instituto Nacional do Livro; Lúcio Costa já havia sido nomeado interventor na Escola Nacional de Belas Artes em 1930 por Francisco Campos, foi convidado por Capanema para conceber e executar o projeto do novo prédio do ministério, conhecido como "Palácio da Cultura", além de participado do projeto da Cidade Universitária e ocupado cargo de Diretor de Estudos e Tombamentos no SPHAN; finalmente, o seu chefe de gabinete, Carlos Drummond.

Segundo Durand (1991, p.6), o Ministério converteu-se em um "território neutro" onde se entrincheiraram os modernistas, gozando de uma liberdade de movimento e expressão sem paralelo em outras instâncias. É provável que essa relação tenha sido facilitada pela presença de Carlos Drummond, além da formação de Capanema entre a intelectualidade mineira. Contudo, não podemos deixar de levar em consideração o fato de que havia um profundo interesse dos intelectuais modernistas em contribuir, de uma forma ou de outra, com o projeto de nacionalização da cultura e difusão de uma nova identidade cultural. 
Em busca de uma modernidade nacional: o movimento modernista e o projeto político-cultural do regime Vargas

Os esforços de Villa-Lobos e Mário de Andrade no sentido de influenciar o ministério na criação de projetos de estudo e ensino da música nacional também são bem reveladores. Villa-Lobos propõe ao ministro um projeto de ensino de música e canto orfeônico, defendendo o interesse nacional e pátrio do projeto que visava "zelar a execução correta dos hinos oficiais, intensificar o gosto e a apreciação da música elevada e encaminhar as tendências folcloristas da música popular nacional" (VILLA-LOBOS apud SCHWARTZMAN, BOMENY \& COSTA, 2000, p. 110). Mário de Andrade também propôs ao ministro um projeto que, nas palavras do próprio Mário, "redige as bases para uma entidade federal destinada a estudar o folclore musical brasileiro, propagar a música como elemento de cultura cívica e desenvolver a música erudita nacional" (ANDRADE apud SCHWARTZMAN, BOMENY \& COSTA, 2000, p. 108).

A confluência dos esforços para criação e desenvolvimento do SPHAN no fim da década de 30 é muito significativa. Inúmeros intelectuais modernistas participaram das atividades organizadas pelo diretor Rodrigo Melo Franco de Andrade, colaborando de diversas maneiras para o desenvolvimento de um propósito que era excepcionalmente modernista: pesquisar e preservar bens móveis, imóveis - inclusive, paisagens - que apresentem valor histórico, etnográfico ou artístico de acordo com o interesse nacional.

Ora, essas propostas evidenciam um significativo interesse no projeto de nacionalização das artes e da cultura, levando em consideração, inclusive, o aspecto cívico e pedagógico desse projeto que envolve a formação de uma consciência nacional. Os intelectuais modernistas eram reconhecidos pelo Estado Novo como protagonistas de uma inteligência nacional, sendo chamados a colaborar com o regime por conta do seu profundo envolvimento, desde a década de 20, com a formulação mais ou menos consciente de um estatuto de brasilidade.

Analisando a presença do modernismo no Ministério Capanema, Simon Schwartzman afirma que:

"Era sem dúvida no envolvimento dos modernistas com o folclore, as artes, e particularmente com a poesia e as artes plásticas, que residia o ponto de contato entre eles e o ministério. Para o ministro, importavam os valores estéticos e a proximidade 
com a cultura; para os intelectuais, o Ministério da Educação abria a possibilidade de um espaço para o desenvolvimento de seu trabalho, a partir do qual supunham que poderia ser contrabandeado, por assim dizer, o conteúdo revolucionário mais amplo que acreditavam que suas obras poderiam trazer." (SCHWARTZMAN, BOMENY, \& COSTA, 2000, p.80).

A nosso ver, além do mútuo interesse no desenvolvimento de linguagens artístico-culturais nacionais, havia um ponto de confluência mesmo no aspecto crítico e inovador da proposta modernista. Obviamente, se pensarmos a partir das perspectivas políticas e mesmo partidárias, as divergências eram profundas. Entretanto, não podemos negligenciar o fato de que tanto os utópicos modernistas, quanto os autoritários do regime mantinham uma linha de identificação e autoimagem vinculada à criação e propagação do novo, à atualização do país, nos mais diversos âmbitos, a partir do cenário contemporâneo.

Como dissemos em outro momento, a perspectiva modernista não era uma volta ao passado, nem mesmo um olhar romântico para os elementos portadores da nacionalidade. Não se tratava exclusivamente da tentativa de representar o espírito nacional através de uma arte prenhe de elementos populares e tradicionais. A utopia modernista pautava-se no cruzamento do tempo "estático" do tradicional e do popular, vinculado a um lento processo de sedimentação nacional, com o tempo "veloz" e "dinâmico" do cenário contemporâneo e das novas vanguardas culturais. Ela também visava à nacionalização da linguagem modernista, ao mesmo tempo em que previa o desenvolvimento da arte brasileira como arte universal.

Em suma, havia um enorme interesse em sincronizar esses diferentes tempos, instâncias e realidades.

Ao contrário do modernismo europeu, os modernismos latinoamericanos e brasileiro não partiam da crítica ao excesso de civilização e à guerra tecnológica, desdobrando-se em uma fuga para o exótico. Não havia a possibilidade de descansar no Outro, porque o Outro, de algum modo, éramos nós mesmos. O seu ponto de partida era, na verdade, uma crítica à civilização importada e ornamental que havia sido implantada no país, 
Em busca de uma modernidade nacional: o movimento modernista e o projeto político-cultural do regime Vargas

principalmente na belle époque brasileira. O esforço de nacionalização, a busca por uma identidade autêntica estava diretamente vinculada ao desejo de destituir esse espírito e modo de conduta importado, postiço.

... o projeto estético, que é a crítica da velha linguagem pela confrontação com uma nova linguagem, já contém em si seu projeto ideológico. $\mathrm{O}$ ataque às maneiras de dizer se identifica ao ataque às maneiras de ver (ser, conhecer) de uma época (LAFETÁ, 2000, p.20).

A crítica à civilização ornamental não se desdobrava em uma volta às origens, ao passado. Em última medida, o que estava em pauta era a implantação do que seria uma "civilização" autenticamente brasileira, capaz de conciliar o local e o universal.

Avanço mesmo que, enquanto o brasileiro não se abrasileirar, é um selvagem. Os tupis nas suas tabas eram mais civilizados que nós nas nossas casas de Belo Horizonte e S. Paulo. Por uma simples razão: não há Civilização. Há civilizações. Cada uma se orienta conforme as necessidades e ideais duma raça, dum meio e dum tempo (...). Nós, imitando ou repetindo a civilização francesa, ou a alemã, somos uns primitivos, porque estamos ainda na fase do mimetismo (...). Nós só seremos civilizados em relação às civilizações o dia em que criarmos o ideal, a orientação brasileira. Então passaremos da fase do mimetismo pra fase da criação. E então seremos universais, porque nacionais (ANDRADE, 1982, p, 12).

Levando em consideração que a palavra civilização já não portava mais o significado oitocentista e tendia a ser substituída pelo termo modernidade, o que estava em jogo era a busca por uma modernidade nacional. Vislumbra-se a possibilidade de que a realização de um extenso 
processo de renovação cultural seria capaz de instaurar um novo equilíbrio, uma nova ordem.

O apelo do novo tendia a incorporar a febre nacionalista do pós-guerra, fundindo a mística do novo, da originalidade e da pureza, com o anseio de uma nova ordem social e a redescoberta de uma magia oculta das raízes (SEVCENKO, 1992, p. 219).

Por mais que a perspectiva estado-novista fosse consideravelmente conservadora, não há como negar que havia um projeto de modernização do país em curso. Até certo ponto, argumenta-se que a modernização das estruturas econômicas e sociais teria se dado de forma espontânea. Mas é certo que a partir do Estado Novo, o novo regime político vai empreender um esforço enorme no sentido de controlar e guiar esse processo de modernização, vinculando-o ao programa de integração nacional e emancipação econômica do país. Como dissemos, foi justamente por conta dessa preocupação que vários grupos imbuídos de uma perspectiva modernizadora foram inseridos nos espaços estatais ou chamados a colaborar com os mesmos. O mesmo ocorreu com grupos que pudessem contribuir com a formação de uma mentalidade nacional alinhada a esse processo ou mesmo que servissem como símbolos de modernidade. Os três casos se aplicam aos intelectuais modernistas que participaram direta ou indiretamente do regime Vargas.

Desse modo, as perspectivas política e cultural se interpenetram a partir de um mesmo objetivo: o projeto nacional de integração cultural e modernização socioeconômica do país. Facções políticas e intelectuais estão sintonizadas na mesma faixa, compartilhando de visões e valores comuns, de modo que são capazes de se reconhecer enquanto responsáveis por diferentes funções em um mesmo projeto nacional. Só que ao contrário do projeto republicano de 1870, essa nova proposta parte de uma perspectiva cultural da nacionalidade e do problema da integração, assumindo uma postura mais "otimista" e buscando "construir e administrar sua própria temporalidade sobre uma base endógena" (PÉCAULT, 1990, p. 93).

Em suma, não se trata mais de ser uma civilização como as civilizações europeias. Mas de ser um novo Brasil, moderno e autenticamente nacional. 
Em busca de uma modernidade nacional: o movimento modernista e o projeto político-cultural do regime Vargas

Percebemos que ao longo das décadas de 30 e 40 se configura uma articulação muito específica entre as vertentes modernistas e o Estado brasileiro. Articulação baseada no ímpeto nacionalizante e modernizador que aparece na forma de um "projeto nacional". "Projeto nacional" na medida em que configura uma aglutinação de relações simbólicas (com valores, crenças, ideais, sentimentos, etc.) constituída, sobretudo, pelo esforço intelectual de uma geração de pensadores preocupados com a identidade nacional e a renovação cultural do país, combinado com o esforço político de um novo regime. Um projeto que elege e consolida o moderno, a inovação cultural e socioeconômica, o discurso técnicocientífico, aliados ao popular, o nacional, os traços originais da cultura brasileira, como os principais critérios simbólico-normativos que modelarão todo um horizonte cognitivo e moral. Um arranjo históricosocial que constituí, na medida mesma em que anuncia, as ideias de Brasil, brasilidade, povo, nação, modernidade que povoarão o imaginário, as crenças e os afetos das décadas subsequentes.

\section{Referências Bibliográficas}

ABREU, Marcelo de Paiva. O Brasil e a economia mundial (1929-1945). In FAUSTO, Boris (org.). O Brasil Republicano: economia e cultura (1930-1964). Rio de Janeiro: Bertrand Brasil, 1996. Coleção História Geral da Civilização Brasileira. T. 3, v. 4.

AMARAL, Aracy A. Artes plásticas na Semana de 22. São Paulo: Ed. 34, 1998.

ANDRADE, Mário de. Aspectos da literatura brasileira. São Paulo: Martins, 1972.

A lição do amigo: cartas de Mário de Andrade a Carlos Drummond de Andrade anotadas pelo destinatário. Rio de Janeiro: José Olympio, 1982.

ARRIGHI, Giovanni. A ilusão do desenvolvimento. Petrópolis: Editora Vozes, 1997. 
DINIZ, Eli. O Estado Novo: estruturas de poder e relações de classe. In: FAUSTO, Boris (org.): O Brasil Republicano: sociedade e política (1930-1964). Rio de Janeiro: Bertrand Brasil, 1996. Coleção História Geral da Civilização Brasileira. T. 3, v. 3.

DURAND, José Carlos. Negociação política e renovação arquitetônica: Le Corbusier no Brasil. Revista Brasileira de Ciências Sociais, São Paulo, no 16, julho de 1991. Não paginado

LAFETÁ, João Luiz. 1930: a crítica e o modernismo. São Paulo: Ed. 34, 2000.

MICELI, Sérgio. Intelectuais e classe dirigente no Brasil (1920-1945). São Paulo: DIFEL, 1979.

OLIVEIRA, Lúcia Lippi; GOMES, Eduardo Rodrigues; WHATELY, Maria Celina. Elite intelectual e debate político nos anos 30: uma bibliografia comentada da revolução de 1930. Rio de janeiro: Fundação Getúlio Vargas, 1980.

Questão nacional na primeira república. São Paulo: Brasiliense, 1990.

ORTIZ, Renato. Cultura brasileira e identidade nacional. São Paulo: Brasiliense, 2006.

PÉCAULT, Daniel. Os Intelectuais e a Política no Brasil: entre o povo e a nação. São Paulo: Ática, 1990.

PEREIRA, Miguel Alves. Arquitetura, texto e contexto: o discurso de Oscar Niemeyer. Brasília: Editora Universidade de Brasília, 1997.

SANTOS, Alessandra X.; SILVA, Andressa A.; DANTAS, Wesley N. (Orgs.). Ricardo Severo: a arte tradicional no Brasil. 19E20, Rio de Janeiro, v. 7, n. 1, jan./mar. 2012. 
Em busca de uma modernidade nacional: o movimento modernista e o projeto político-cultural do regime Vargas

SCHWARTZMAN, Simon; BOMENY, Helena M. B.; COSTA, Vanda M. R. Tempos de Capanema. Rio de Janeiro: Paz e Terra, 2000

SEVCENKO, Nicolau. Orfeu extático na metrópole: São Paulo, sociedade e cultura nos frementes anos 20. São Paulo: Companhia das Letras, 1992.

SKIDMORE, Thomas. E. Brasil: de Getúlio a Castello. São Paulo: Companhia das Letras, 2010.

TORRES, Alberto. O problema nacional brasileiro. São Paulo: Companhia Editora Nacional, 1978.

VIANNA, Hermano. O mistério do samba. Rio de Janeiro: Jorge Zahar, 2002.

Enviado: em:

13/04/2015

Aprovado em:

27.06.2015 